\title{
Contesting Anticompetitive Actions Taken in the Name of the State: State Action Immunity and Health Care Markets
}

\author{
Clark C. Havighurst \\ Duke University Law School
}

\begin{abstract}
The so-called state action doctrine is a judicially created formula for resolving conflicts between federal antitrust policy and state policies that seem to authorize conduct that antitrust law would prohibit. Against the background of recent commentaries by the federal antitrust agencies, this article reviews the doctrine and discusses its application in the health care sector, focusing on the ability of states to immunize anticompetitive actions by state licensing and regulatory boards, hospital medical staffs, and public hospitals, as well as anticompetitive mergers and agreements. Although states are free, as sovereign governments, to restrict competition, the state action doctrine requires that "the state itself" make the decision to do so. Partly on the basis of problems in the political environment, the article criticizes courts for using a mere "foreseeability" test to decide whether a state legislature sufficiently authorized competitors to act in contravention of clear federal policy: "Few things are more foreseeable than that a trade or profession empowered to regulate itself will produce anticompetitive regulations."
\end{abstract}

In the 1970s, the federal antitrust agencies began an ambitious campaign to transform health care markets from their traditional status as minipolities governed by industry elites into competitive arenas responsive to consumer choices. From the beginning, however, they and other pursuers of this vision had to reckon with publicly as well as privately imposed restraints of trade. Thus, while antitrust enforcement targeted the usual suspects - private cartels, group boycotts, anticompetitive mergers, and monopolistic practices by dominant firms - many constraints on market forces were relatively invulnerable to antitrust challenges because they

Journal of Health Politics, Policy and Law, Vol. 31, No. 3, June 2006 DOI 10.1215/03616878-2005-008 @ 2006 by Duke University Press 
were fostered by state governments. Indeed, in many cases, the antitrust agencies could promote the cause of competition only through advocacy, seeking to persuade state policy makers that relatively free competition would serve their citizens better than regulatory policies of various kinds. ${ }^{1}$ On the other hand, state legislation, sponsorship, or authorization does not necessarily bar antitrust action to correct an anticompetitive situation, act, or practice. Whether a particular state or local government initiative restrictive of competition forecloses agency or judicial scrutiny of particular activities for compatibility with national competition policy is governed principally by the so-called state action doctrine of federal antitrust law. This article discusses this legal doctrine, showing how it defines significant stretches of the borderline between federal and state authority over American health care.

As the law now stands, a state, as a sovereign government in a federal system, is generally free to adopt policies for particular markets that are inconsistent with the general national policy, embodied in the antitrust laws, of trusting competition and market forces to promote consumer welfare and achieve economic objectives. The Supreme Court, however, in a number of rulings, has laid down certain principles for determining whether a state has in fact done enough to effectively confer "state action immunity" on public or private actors charged with federal antitrust violations. These principles were extensively reviewed in a 2003 report on the state action doctrine by a staff task force of the Federal Trade Commission (FTC) (Office of Policy Planning 2003). That report elaborated a number of situations in which broad interpretations of the state action doctrine by lower federal courts have precluded application of federal antitrust law when federal policy arguably should have prevailed. The document that provides the occasion for the instant symposium - the federal antitrust agencies' 2004 report titled Improving Health Care: A Dose of Competition (FTC/Department of Justice [DOJ] 2004) _ added little to the FTC staff's 2003 study's insights on state action immunity beyond supplying some examples of how state limitations on competition and judicial confusion in applying the state action doctrine can adversely affect competition in health care. This article, rather than duplicating the 2003 FTC report's

1. The Federal Trade Commission, in particular, has an active advocacy program, including staff reports on various competition issues, submissions to state legislatures on the merits of pending proposals impacting competition, and briefs amicus curiae in private antitrust litigation presenting overarching legal issues that the agency deems important. Some of the agency's efforts in the health care sector are described in the FTC/DOJ report (FTC/DOJ 2004: chap. 8). 
legal analysis, ${ }^{2}$ first describes the federal-state situation for a general audience and then identifies some specific state action issues arising in health care markets that both illustrate important legal points and highlight the importance of the state action doctrine for national health policy.

\section{State Action Immunity}

Although the Sherman Antitrust Act of 1890 established the fundamental national policy of promoting consumer welfare by relying on competition to guide and constrain private commercial activity, that venerable statute has never been understood to preempt all state authority to interfere with competition in interstate commerce. Instead, the Supreme Court has taken the position that the Fifty-first Congress did not intend, in passing the Sherman Act, to limit the sovereignty of the states in their traditional areas of concern. In a principal early case, the Court stated, "In a dual system of government in which, under the Constitution, the states are sovereign, save only as Congress may constitutionally subtract from their authority, an unexpressed purpose to nullify a state's control over its officers and agents is not lightly to be attributed to Congress." 3 However, the Court has also long viewed the pro-competition policy expressed in the antitrust laws as a fundamental one. ${ }^{4}$ The state action doctrine results from the Court's effort to reconcile the demands of federalism with the strong national policy favoring competition.

Because the federal antitrust statutes apply only to private anticompetitive conduct, they present no obstacle at all to state legislatures' direct exercise of regulatory power. Thus, there can be no antitrust objection to such anticompetitive legislation in the health sector as entry-limiting certificate-of-need laws, statutory prohibitions on health insurers' refusing to deal with "any willing provider" (to reward selected providers with increased volume in return for price or other concessions), or legislative mandates that certain benefits be provided in health insurance contracts. ${ }^{5}$

2. See also In re South Carolina State Board of Dentistry, FTC No. 9311 (July 30, 2004) (the FTC's latest ruling on the state action defense, reviewing principles); Page and Lopatka (1994); Page (1987).

3. Parker v. Brown, 317 U.S. 341, 350-351 (1943).

4. The Supreme Court has long refused, for example, to "lightly" infer from federal regulatory legislation a congressional intent to set aside antitrust requirements. For example, see National Gerimedical Hospital and Gerontology Center v. Blue Cross, 452 U.S. 378, 388-389 (1981) (reconciling federal health planning legislation with the antitrust laws); and Gordon $v$. New York Stock Exchange, 422 U.S. 659, 682 (1975).

5. Although the federal antitrust laws have nothing to say about overt state legislative restrictions on competition and freedom of contract, the Employee Retirement Income Security Act of 
Some state legislation, however, arguably empowers various categories of health professionals or other competitors, acting collectively, to restrict their own competitive freedom-just the kind of interference with the competitive process that section 1 of the Sherman Act, which prohibits "every contract, combination . . . or conspiracy in restraint of trade," was intended to prevent. It is in cases of this kind, and others where a state has arguably authorized what the antitrust laws would prohibit, that the Supreme Court's federalism gloss on the Sherman Act allows courts to determine whether the state's authorization of anticompetitive actions taken by certain state and local government officials, or by private parties purporting to act with state authority, was sufficient to trump national competition policy. The indicated inquiry is designed to determine whether the resulting harm to competition was in fact consciously authorized by the state itself, as a sovereign government, or was instead the idea of some lesser agency or of private parties acting under "a gauzy cloak of state involvement." 6 The so-called Midcal test for state action immunity, named after the 1980 opinion that first announced it, ${ }^{7}$ provides a kind of safe harbor for states wishing to depart from competition in derogation of antitrust principles. As the case law has generally framed the issue, the question is rarely whether the federal antitrust statutes entirely preempt a particular state policy choice, making the latter unconstitutional under the Supremacy Clause. Instead, the question is whether, in view of a state's involvement, the Sherman Act should be enforced in the particular case-in other words, whether the anticompetitive conduct in question, ostensibly blessed in some way by state government, violates federal law nevertheless.

1974 (ERISA) preempts some state efforts to regulate employee health benefits. For example, see Kentucky Association of Health Plans, Inc. v. Miller, 538 U.S. 329 (2003) (holding "anywilling-provider" law aimed at insurers not preempted by ERISA); and Metropolitan Life Ins. Co. v. Massachusetts, 471 U.S. 724 (1985) (holding state-mandated benefit requirement applicable to insurers not preempted - though a similar mandate aimed at self-insured employers would be). Although certificate-of-need laws are unobjectionable under federal policy-and indeed were mostly enacted under federal compulsion in the Health Planning and Resources Development Act of 1974 (repealed in 1986) - questions occasionally arise concerning the application of antitrust law to private market-division agreements allegedly reached in aid of state-sponsored health planning. For example, see Department of Justice (2005) (rejecting West Virginia planning agency's claim that state statute provided state action immunity for hospitals' market-sharing agreement).

6. California Retail Liquor Dealers Association v. Midcal Aluminum, Inc., 445 U.S. 97, 106 (1980) ("The national policy in favor of competition cannot be thwarted by casting . . . a gauzy cloak of state involvement over what is essentially a private price-fixing arrangement").

7. Ibid. 
The Midcal test for state action immunity is deceptively easy to state. Under it, a state or local policy choice against competition will be respected if the state, as a sovereign, has both (1) "clearly articulated" its alternative policy, including its intention to reject competition as a policy instrument, and (2) provided in some way for "active supervision" of actions taken pursuant to the policy in question. The "clear articulation" requirement is designed to ensure that "the state itself," either through its legislature or its supreme court, has openly and in fact adopted the policy that is arguably at odds with federal competition policy. Because lesser agencies or subdivisions of state government cannot qualify as the state itself, ${ }^{8}$ they must, in order to enjoy or confer state action immunity, have clear legal authority from the sovereign for any anticompetitive actions they take or authorize. The active-supervision requirement seems intended to secure some state-level assurance that it is still state policy, and not some private interest, that is being advanced when the state's anticompetitive policy is implemented in a given case; it may also embody a federal expectation that any state that denies consumers the benefits of competition must provide some alternative protection for their interests. ${ }^{9}$ In general, the Midcal doctrine has the virtue of preventing federal courts and antitrust enforcers from simply vetoing the well-considered policy choices of state legislatures while still giving the national policy favoring competition some effect in situations where subordinate state officials may have exceeded their authority to restrict competition or where private interests may have used the state as a cover for anticompetitive activities.

Discussions of the state action doctrine usually begin by citing Parker v. Brown, a Depression-era case establishing that, under the Eleventh Amendment, "the state itself" is not subject to being sued by a private party in federal court for violating the Sherman Act. ${ }^{10}$ Although sometimes referred to as "the doctrine of Parker v. Brown," the state action doctrine is much broader than the Parker holding, consisting of certain preconditions for applying the Sherman Act to subordinate state agencies that do not qualify as the state itself and to private parties purporting to exercise state-granted powers. ${ }^{11}$ Later cases eventually confirmed

8. Although often disputed, this point was reaffirmed by the FTC in its recent opinion in South Carolina State Board; see note 2 above.

9. FTC v. Ticor Title Insurance Co., 504 U.S. 621 (1992) (holding that, to satisfy the Midcal requirement, state oversight must be effective, not just nominal).

10. Parker v. Brown, 317 U.S. 341, 350-351 (1943).

11. Indeed, the Parker case presented no real conflict between federal and state policies, since federal agricultural legislation at the time clearly contemplated the cartel-like activity at issue in the case, a collusive private proration scheme for marketing California raisins. 
the principle that Congress's general policy favoring competition was not intended to override the prerogative of a state to set competition aside. But those cases were preceded by the Supreme Court's 1944 decision in South-Eastern Underwriters, which applied the Sherman Act to firms in the insurance industry despite state regulation arguably authorizing the trade restraints with which they were charged..$^{12}$ In response to that decision, Congress enacted the McCarran-Ferguson Act, expressly exempting "the business of insurance" from the federal antitrust laws insofar as it is regulated by a state. ${ }^{13}$ Its statutory test for applying federal law to state-regulated insurers is very similar to the state action doctrine as subsequently developed. Indeed, there is no reason why the McCarran and Midcal tests should not be essentially the same in comparable circumstances. Even though the former test is embodied in explicit legislation rather than inferred from congressional intent in passing the Sherman Act, it was enacted well before the Supreme Court arrived at the Midcal test to govern other situations in which a state substitutes regulation for competition. The McCarran Act can be viewed as legislative precedent confirming the Court's later ascription to the Fifty-first Congress of an intention not to displace responsible state regulation.

The black-letter simplicity of the two-part Midcal formulation of the state action doctrine, though much appreciated by law students, belies the difficulty of applying its tests to different kinds of state legislation and different governmental entities. As later discussion of specific issues will show, the health care sector provides a helpful laboratory for observing and evaluating different applications of the doctrine.

\section{The Hazards of Entrusting Health Care Competition Policy to the States}

The state action doctrine is generally significant because it means that the federal antitrust laws' requirement that competitors compete is not necessarily the law of the land. It has special significance for competition in health care, moreover, because state governments regularly confer on authorities closely aligned with professional and other private interests powers that may be used to affect adversely the competitiveness of health care markets. However, if courts do not confer state action immunity too freely, federal antitrust law, though governing only private conduct, can 
prevent such delegations of policy-making power and make "the state itself" take direct responsibility for health-sector competition policy.

Like much of the rest of American health care law and policy, competition policy for the health care sector is incoherent in large part because responsibility for making it is widely shared. To be sure, antitrust law now places significant limits on the ability of private interests to set their own competitive rules, but responsibility for competition policy is still arbitrarily divided between the states and the federal government. ${ }^{14}$ Congress could, of course, exercise its constitutional power over interstate commerce to assume virtual plenary authority over modern health care. It has instead, however, allowed the states to retain most of their traditional powers to make health care law. Under their police powers, for example, the states are largely responsible for ensuring the quality of care, which they do in part by restricting entry through exclusionary licensing, by heavily regulating institutions and individuals participating in patient care, and by supplying tort remedies for professional and institutional negligence. ${ }^{15}$ For its part, the federal government has assumed preponderant authority over health care financing, both public and private. The Employee Retirement Income Security Act (ERISA), for example, precludes state lawmaking on many subjects related to employee health benefits. As the McCarran-Ferguson Act and the state action doctrine make clear, though, Congress has not chosen to dictate competition policy to the states even though the latter's regulatory powers are frequently exercised in derogation of market forces. ${ }^{16}$

State regulation in the name of quality assurance and consumer protection tends to be overly exclusive, prescriptive, and anticompetitive in part because it emerges from a political process that is highly responsive to the concerns of industry participants and comparatively neglectful of the true interests of ordinary consumer-voters. ${ }^{17}$ Indeed, because trade

14. See Havighurst (2000) (discussing "the disorderly state of health care law today" and observing that both "Congress and state legislatures ... lack responsibility for, or control over, many aspects of the health care system that their decisions affect. Both legislatures and courts are also influenced ... by overarching conventions and paradigms that, lacking plenary power, they cannot easily reexamine or alter").

15. To the extent that they are prescriptive and invariable by contract, the standards that the tort system enforces against health care providers can be viewed as regulatory in nature and thus antithetical to market forces. What makes them politically legitimate is unclear, since they are supplied by the medical profession (and medical experts) rather than by any politically accountable authority. Nor have they been validated by consumer choices in a working market. But obviously there is little opportunity for launching antitrust attacks on such standards.

16. But see note 5 above.

17. But see Arrow (1963: 966) (a classic early article attributing the prevalence of exclusionary licensure for physicians more to the need for a public-interested legislative response to "uncertainty in the mind of the consumer as to the quality of the product" than to physician rent-seeking). 
restraints embodied in state law are so likely to reflect effective lobbying by private rent-seekers, it may seem arbitrary, or naive, for the state action doctrine to distinguish as sharply as it does between publicly and privately imposed restraints of trade. Intergovernmental comity, however, requires that federal antitrust law not be premised on too cynical a view of state legislative politics. In any event, it would not be reasonable to look to antitrust law to overcome defects of representative democracy, even when the government's actions undermine competition. Indeed, an important antitrust principle, the so-called Noerr-Pennington doctrine, expressly blocks application of the Sherman Act to preclude competitors from collaborating to harm competition by obtaining governmental action harmful to their competitors or to consumers. ${ }^{18}$ However, even though there are good reasons for not relying on antitrust law to correct all anticompetitive situations created by governmental action, some realism about interest-group influences in state legislative politics would seem to be in order in applying the Midcal tests. Thus, courts can reasonably demand that anticompetitive state actions, when they are taken, at least be taken openly and explicitly by accountable legislators, not behind closed doors or by others to whom the legislature has delegated its power to make competition policy. ${ }^{19}$

There is another reason, besides the undue political influence of special interests and the relative ignorance or apathy of voters, why state political choices may unduly restrict competition in the private provision and financing of health care-and deserve only limited deference under the state action doctrine. Because of the large federal and state tax subsidy for employer-purchased health coverage, political leaders are certain to give substantially greater weight to the presumed or alleged benefits of quality-enhancing regulatory requirements than to those measures' likely costs to consumers. This subsidy, by reducing the after-tax cost of coverage and making employers its primary purchasers, ensures that consumervoters never see the full cost of whatever coverage they enjoy and rarely perceive even dimly the marginal costs to themselves of legal and regulatory mandates imposed in the name of quality assurance. The resulting political bias not only favors more and better health care, without appreciable regard to its cost to consumers, but also plays out in a systematic undervaluing of competition offering consumers a variety of price/quality

18. This doctrine is briefly discussed, with references, following the discussion of the state action doctrine in Dose of Competition (FTC/DOJ 2004: chap. 8).

19. The state action doctrine's requirement that legislators themselves must legislate departures from national competition policy echoes concerns that underlie the nondelegation principle in administrative law. See generally Pierce, Shapiro, and Verkuil (1992: sec. 3.4). 
options. ${ }^{20}$ Distorted incentives also ensure too-ready public and political acceptance of uneconomic professional and industry standards as appropriate measures of performance in private contracts, regulatory standard setting, and malpractice suits and other kinds of litigation. ${ }^{21}$

Because state political climates tend to be both friendly to professional interests and neglectful of consumer concerns about cost, state legislative authority over competition policy in health care has generally been exercised, not to challenge, but to perpetuate the tradition of self-regulation in the various professions. When the antitrust laws were first actively enforced against professionals in the 1970s, there was already in place a strong presumption, cultivated by professionals themselves, against relying on competition and consumer choice to guide developments in the health care sector. Antitrust enforcers had significant success in challenging restraints that private professional organizations had adopted and imposed in the era of self-regulation, frequently offering evidence of their net harmfulness to consumers. But many similar restraints were embodied or came to be embodied in state law and were thus harder for the agencies and private litigants to attack. The state action doctrine has been an important obstacle to mounting an effective, all-out antitrust challenge to professional power as it survives in various segments of the health sector. Professional ideology thus retains much of its earlier dominance in American health care law and policy. ${ }^{22}$

The special bias against competition and cost concerns and in favor of the professional paradigm that is detectable in state health policy choices raises not only the cost of health care to consumers but also the stakes in applying the state action doctrine to particular cases arising in the health care sector. The following examples of state action issues are useful in appraising both the state of competition in health care today and the state of the law on state action immunity. It should become apparent that those who pay premiums for health coverage pay a high price for Congress's failure to insist that states respect the pro-competition policy expressed in the federal antitrust laws.

20. For discussions of the little-noticed political consequences of the tax subsidy, see Havighurst (2002: 77-94) and Havighurst (2001).

21. See note 15 .

22. See note 15. "It is simply ironic that the same legal system that with one arm launched an antitrust initiative successfully challenging overt efforts by the medical profession to exercise decision-making authority has with its other arms given medical interests a monopoly over the most important economic decisions affecting American health care" (Havighurst 2000). 


\section{The State Action Doctrine at Work}

\section{State Licensing Boards}

Much anticompetitive state regulation of health care markets is implemented by state-appointed boards charged with licensing one or more health professions or occupations and also with regulating the conduct of the practitioners they license. Although practices vary, many states appoint the members of such boards from lists of nominees provided by the professional or occupational group being regulated. A public member or two is usually appointed as well, but such boards are rarely less than friendly to and supportive of the licensed group. Indeed, most boards are more professional than governmental in character, signifying their roots in the tradition of professional self-regulation. Such an origin suggests that licensing boards may have little enthusiasm for competition. ${ }^{23}$

True to their origins and cartel-like character, licensing boards constituted principally by representatives of the regulated group not only adopt licensing standards that raise entry costs and limit the number of competitors in the field but also frequently adopt regulations that directly restrain trade. ${ }^{24}$ Many, for example, maintained prohibitions on all but the most innocuous forms of professional advertising at least until the Supreme Court ruled in 1976 that state-imposed restrictions on truthful advertising violated constitutional guarantees of free speech, including the right of consumers to receive the commercial information being suppressed. ${ }^{25}$ State boards also tend to be protective of the domains of the professionals they regulate, fighting incursions by unauthorized practitioners and assisting their licensees in dividing markets with other occupations. A common anticompetitive objective of the boards has been to suppress such commercial practices by licensed practitioners as practicing under trade names or on the premises of commercial establishments, allowing corporate middlemen to retail their services, and joint venturing with professionals of other kinds. ${ }^{26}$

23. The classic work on professional dominance in medicine is by Starr (1982). For conflicting views on the general legitimacy of professional self-regulation, see Freidson (2001) and Havighurst (2003) (reviewing Freidson's book).

24. Entry controls also ensure an artificial homogeneity among competitors that may facilitate their cartel-like coordination of prices and practices.

25. Virginia State Board of Pharmacy v. Virginia Citizens Consumer Council, Inc., 425 U.S. 748 (1976). Similar restrictions adopted by private competitor groups would violate the antitrust laws. But see California Dental Association v. FTC, 526 U.S. 756 (1999) (5-4 decision raising the FTC's burden of proof in challenging private restrictions on professional advertising), criticized in Havighurst (2001).

26. See Dose of Competition (FTC/DOJ 2004: 60-61) (describing the FTC's extensive, though ultimately unsuccessful, attempt in the 1980s to adopt the so-called Eyeglass Rule aimed at invalidating state-imposed restrictions on the commercial practice of optometry). 
On a few occasions, federal antitrust agencies and courts have treated anticompetitive regulatory rules adopted by state licensing boards as actual antitrust violations by the practitioner-dominated boards themselves. In one such case, for example, the FTC successfully challenged restrictions that an optometry board had put on advertising by optometrists despite a state policy opposed to such restrictions. ${ }^{27}$ In a case decided early in the antitrust agencies' engagement with restraints in markets for professional services, the DOJ obtained antitrust relief against the Texas State Board of Accountancy for using broad powers to adopt a regulatory prohibition against engaging in competitive bidding for professional work. ${ }^{28}$ There were few follow-up cases of this kind, however, perhaps because boards avoided similarly egregious restraints ${ }^{29}$ or because the federal agencies felt constrained by federalism considerations or pressured to leave politically influential professionals alone. ${ }^{30}$ In any event, in a private suit resolved in 1998, the Fifth Circuit court of appeals overruled its earlier decision in the Texas State Board case and granted broad antitrust immunity to a Louisiana licensing board and its practitioner members engaged in regulating accountants. ${ }^{31}$ It reached this result by analogizing licensing boards to municipalities, to which the Supreme Court had extended broad state action immunity in some early cases. ${ }^{32}$ In those cases, the Court took the position that mere foreseeability of anticompetitive regulation in the exercise of general municipal powers was sufficient to meet the clear-articulation requirement of the Midcal test. It also relaxed the active-supervision requirement for municipalities, deeming that requirement more appropri-

27. In re Massachusetts Board of Registration in Optometry, 110 F.T.C. 549 (1988).

28. United States v. Texas State Board of Public Accountancy, 593 F.2d 919 (5th Cir. 1979).

29. The restraint in Texas State Board was adopted only after licensees approved it in a referendum and closely resembled the more obviously private restraint of trade roundly condemned by the Supreme Court in National Society of Professional Engineers v. United States, 435 U.S. 679 (1978) (rejecting quality-of-service defense, of the kind typically advanced in support of trade restraints in markets for professional services, as "a frontal assault on the basic policy of the Sherman Act").

30. The FTC's eyeglass initiative (see note 26 above) signified an agency preference for proceeding by prospective rule, justified by empirical evidence of net harm to consumers, rather than by the even more politically sensitive route of charging individual state boards with antitrust violations. The FTC's latest challenge to a state board, the South Carolina State Board of Dentistry (note 2), was less sensitive because, like the earlier Massachusetts Board case (note 27), it involved a board action "in direct conflict" with the relevant state statute.

31. Earles v. State Board of Certified Public Accountants, 139 F.3d 1033 (5th Cir. 1998).

32. For example, City of Columbia v. Omni Outdoor Advertising, Inc., 499 U.S. 365 (1991); Town of Hallie v. City of Eau Claire, 471 U.S. 34 (1985). Although the merit of this analogy is questioned below, the Supreme Court invited it by saying in the latter case, "In cases in which the actor is a state agency, it is likely that active state supervision would also not be required, although we do not here decide that issue" (1985: 46 n.10). 
ate for private parties acting anticompetitively under state authority than for a creature of the state itself. The Fifth Circuit court had no difficulty in similarly relaxing the Midcal requirements for a state board staffed by members of the regulated profession.

A strong argument can be made against automatically analogizing state licensing boards to municipalities in applying the Midcal tests. For one thing, the direct political accountability of municipal officials to public opinion, the media, and voters in local elections sharply distinguishes them not only from private parties claiming state action immunity but also from state licensing boards closely allied with the professionals they regulate. Boards of the latter kind obviously manifest the traditional view of professionals as an elite class of citizens who can be trusted to regulate themselves. This was precisely the view of the professions that antitrust enforcers began to challenge in the 1970s, and it would seem to be a mistake for federal courts to make it easy for states to frustrate that national enforcement initiative. In this light, the Fifth Circuit's extension of state action immunity to licensing boards may be thought to give too little weight to federal antitrust policy, too much respect to state politics, and too much weight to federalism values. ${ }^{33}$ It is hard to accept, for example, the court's statement that "the public nature of the board's actions means that there is little danger of a cozy arrangement to restrict competition."34 Indeed, one could not say as much even for municipalities - though there was much wisdom in the Supreme Court's holding in the 1991 Omni Outdoor Advertising case that, despite allegations of a conspiracy between private interests and city officials, the Sherman Act was not intended to redress municipal corruption. ${ }^{35}$

Instead of borrowing from the Supreme Court's respectful treatment of various burdens that municipalities inevitably impose on local businesses, courts applying the state action doctrine should shape their inquiries to give proper weight to federal antitrust concerns as well as federalism. This would mean adopting different tests for different agencies, depending on the likelihood of harm to consumers from anticompetitive regulations. Thus, in deciding how explicit a state legislature must be in authoriz-

33. It is still possible that, even in the Fifth Circuit, an agency adopting a regulation as blatantly anticompetitive as the one in Texas State Board would be expected to have explicit, not just implicit, legislative authority for so doing. But the court's wooden approach to the issue in Earles revealed no appreciation that federal antitrust policy might have something useful to contribute to the regulation of the professions.

34. 139 F.3d at 1041.

35. 499 U.S. at 376-379. Also on the limits of antitrust law for actively correcting defects in political systems, see text accompanying notes $17-19$. 
ing curtailments of competition, they might apply the clear-articulation requirement with special rigor to state boards that appear rooted in the self-regulatory tradition. Certainly the foreseeability test employed in the case of municipalities seems inappropriate in such cases, for few things are more foreseeable than that a trade or profession empowered to regulate itself will produce anticompetitive regulations. Indeed, federal antitrust policy is strong and clear enough that it could reasonably be invoked preemptively when a state legislature creates a board so dominated by the regulated interests that it amounts to a self-regulating cartel. ${ }^{36}$ In any event, federal courts should at least demand that state licensing boards closely allied with the interests they regulate be able to demonstrate explicit, not merely implicit, statutory authority when they undertake to limit competition. ${ }^{37}$ It is perhaps reassuring that, in a thoughtful 1999 en banc opinion denying state action immunity to a public hospital, the Fifth Circuit court of appeals stated that "courts will not infer . . . a policy to displace competition from naked grants of authority. ... . [To do so] would stand federalism on its head. A state would henceforth be required to disclaim affirmatively antitrust immunity, at the peril of creating an instrument ... with [trade-restraining] power the state did not intend to grant." 38

Rather than proposing that the clear-articulation requirement be applied with special rigor to licensing boards carrying on the tradition of selfregulation, the federal antitrust agencies appear to believe that giving greater weight to the active-supervision requirement is the best way to discourage state licensing and regulatory boards from acting in anticompetitive ways. ${ }^{39}$ There is no familiar institutional model for providing state

36. The Supreme Court has made it clear, after all, that states cannot simply cast a "gauzy cloak" over a private conspiracy in restraint of trade. See note 6; see also Parker, 317 U.S. at 351 ("a state does not give immunity to those who violate the Sherman Act by authorizing them to violate it").

37. The suggestion here differs materially from the more deferential one taken in the Office of Policy Planning (2003: 51), which would leave the foreseeability test in place "as a tool for probing the state's intentions and policies, not as an end in itself." But given the clarity and strength of anti-cartel policy, it should not be permissible for a state legislature to delegate trade-restraining powers to an agency that is clearly likely to abuse them. Instead, state legislatures should be expected, under federal policy, to be explicit about their intentions when the harm to competition is clearly foreseeable, as it is in the case of boards dominated by professional interests. This suggestion seems in keeping with views expressed by Professors Lopatka and Page in a consultants' report to the FTC referenced in Office of Policy Planning (2003: 5 n. 4).

38. Surgical Care Center of Hammond v. Hospital Service District No. 1 of Tangipahoa Parish, 171 F.3d 231, 236 (5th Cir. 1999) (en banc).

39. Office of Policy Planning (2003: 55-56) (characterizing state boards beholden to private interests as "quasi-governmental entities that should be subject to active supervision"). See also Dose of Competition (FTC/DOJ 2004: chap. 8, 7). 
oversight of its licensing boards, however, and it would seem awkward for a federal court to prescribe added supervision to supplement a state board's normal political accountability to the legislature, the governor, and the courts. Indeed, for a federal court to declare accountability of the latter kinds inadequate under federal law would seem far more offensive to federalism values than merely expecting a state legislature to be clear about it if it really wants to authorize a state board to restrict competition in some significant way. Thus, rigorous application of the clear-articulation requirement would be not only a more appropriate but also a more effective federal response to the hazards to competition and consumer interests associated with interest-group politics at the state level. Indeed, requiring legislators to reveal their policy choices against competition in substantive statutory provisions, as opposed to conferring implicit trade-restraining powers on thinly veiled agents of special interests, would have the salutary effect of bringing such important policy choices into the open. As presently applied to state boards, the state action doctrine seems to undermine national antitrust policy far more than the original intent of the Sherman Act's drafters requires or than federalism values justify, leaving health professionals and other interest groups easy opportunities to circumvent federal competition policy.

\section{Hospital Staff Privileges}

Hospitals are another place, like state licensing boards, where professional competitors may have opportunities to restrain trade with impunity due to state authority or encouragement. A number of lower federal courts have extended state action immunity to medical staffs and hospitals in cases brought by individual practitioners claiming that a hospital and its medical staff conspired against them for anticompetitive reasons. ${ }^{40}$ In the leading

40. To be sure, most of the many antitrust cases initiated by individual physicians and other practitioners contesting restrictions on their admitting privileges in hospitals have lacked antitrust merit. But there is a real risk that public or private hospitals will allow their organized medical staffs to decide finally which competitors of incumbent staff members may use the hospital's facilities and that the staff will sometimes use this power to prevent competition rather than to advance the interests of the hospital. Sound antitrust analysis would recognize this risk and apply the law roughly as follows: (1) by first characterizing the hospital/staff relationship as a joint venture with important pro-competitive benefits as well as significant anticompetitive potential; (2) by evaluating the structure of the joint venture (under what is sometimes called the "less restrictive alternative" requirement) to see whether the risk of anticompetitive effects is minimized by leaving final decisions, not just nominally but in fact, to the hospital's governing board rather than to the medical staff alone; and finally either (3a) by summarily approving any decisions taken by the governing board if they appear to have a rational basis or (3b) by scrutinizing final decisions made by the medical staff at enough length to determine whether it 
1988 case of Patrick v. Burget, however, the Supreme Court rejected such immunity for a private hospital and a medical clinic that allegedly used its control of the medical staff to disadvantage a competitor. ${ }^{41}$ Applying the second of the two Midcal tests, the Court found that the state, though encouraging peer review in hospitals, had made no provision for reviewing private hospitals' privileges decisions to ensure that state policy was not being violated. Although the Court was undoubtedly right in rejecting state action immunity in Patrick, its reliance on the lack of active supervision was unfortunate because it implied that Midcal's first test, the cleararticulation requirement, was satisfied. Yet the Oregon statute invoked by the hospital, though it anticipated that privileges might be withheld from some competitors, in no way contemplated conduct that would offend federal antitrust policy, properly understood. Indeed, the Oregon legislature expressly assigned responsibility for screening physicians to hospitals, not to physicians deciding independently which of their competitors could use the hospital's facilities. It thus provided no predicate at all for state action immunity, which applies only when state policy conflicts with federal antitrust law.

In passing over the clear-articulation issue without comment in Patrick v. Burget, the Supreme Court missed an opportunity to clarify that hospital staffing decisions, if made by hospitals themselves and not by their medical staffs, are a hallmark of a healthy, quality-oriented competitive market for physician services. Instead, the Court left unchallenged the widespread impression that any denial of privileges is suspect under antitrust policy because it excludes or disadvantages a competitor, when it might have reminded us that there are winners and losers in all market transactions. Moreover, the Court missed a chance to correct another pernicious assumption that can easily lead to misreading the import of statutes like the one in Oregon. This is the view that physicians collectively administering staff privileges in hospitals are engaged in professional self-regulation and acting as agents of their profession. It should be

\footnotetext{
was acting in the hospital's interest or anticompetitively in the interest of its members. Although courts usually reach correct results in staff privileges cases, they have frequently misapplied antitrust principles (including the state action doctrine) in the process, complicating counseling and future cases and necessitating clarifying legislation, the Health Care Quality Improvement Act, in 1986. In any event, the analytic approach suggested here would ensure that candidates for privileges would be selected (or rejected), not by their (horizontal) competitors, but by hospitals themselves, with which they stand in a normal (vertical) market relationship. See generally Havighurst, Blumstein, and Brennan (1998: 687-709) and Havighurst (1984: 1108-1139). 41. 486 U.S. 94 (1988).
} 
the business of antitrust law to contest this view of medical staffs and to clarify that such power as they exercise comes to them, not as professionals qua professionals, but as agents of the institutions that rely on them. The case would also have been a good occasion to make the point that joint ventures between hospitals and their medical staffs to improve the quality of care must be designed and operate in a way that minimizes the inevitable risk to competition. In any event, though the Patrick case left the substantive law of staff privileges still unclear, ${ }^{42}$ it ensured that the state action doctrine itself would rarely be a bar to enforcing the antitrust laws in privileges cases in private hospitals.

In privileges cases involving public hospitals, on the other hand, the state action doctrine obviously has a more central role to play. Denials of privileges are apt to be expressly contemplated in a public hospital's enabling legislation, and some courts, analogizing the hospital to a municipality, have thought that this alone, under the foreseeability principle, should be enough to immunize a hospital and its medical staff from antitrust suits by disgruntled practitioners. ${ }^{43}$ Once again, however, statutory authority to deny privileges does not equate to authority to violate the antitrust laws since not all denials of privileges are anticompetitive in an antitrust sense. Instead, a public (or private) hospital selecting physicians for its medical staff should be viewed simply as a purchaser of physician services, free like any other purchaser to refuse to deal with individual doctors for commercial reasons of its own. A fortiori, a public hospital's statutory authority to deny privileges should not immunize anticompetitive actions its medical staff might take, since the staff comprises private parties with commercial interests of their own and cannot be empowered by the hospital - a subordinate state agency, not the state itself-to restrain trade unlawfully without more explicit authority than an enabling act is likely to provide. Indeed, the active-supervision requirement of the Midcal doctrine should have special significance here, since it would seem to require that the hospital's (state-appointed) governing body itself oversee potentially anticompetitive actions of the medical staff with enough care to ensure that public (i.e., the hospital's) goals, not the interests of the

42. For clarification, see note 40.

43. For example, see Crosby v. Hospital Authority of Valdosta, 93 F.3d 1515 (11th Cir. 1996); Bolt v. Halifax Hospital Medical Center, 891 F.2d 810 (11th Cir. 1990) (immunity found on ground that "when Florida's legislature authorized peer review . . ., it could foresee that [the public hospital] would rely on recommendations made by a physician's peers and refuse to deal with [i.e., boycott] that physician"); and Coastal Neuro-Psychiatric Associates v. Onslow Memorial Hospital, Inc., 795 F.2d 340 (4th Cir. 1986). 
doctors, are being furthered in particular cases. So understood, the state action doctrine would provide a strong inducement for governing boards of public hospitals to participate actively and responsibly in privileges decisions, just as substantive antitrust law should also be understood to do-in the case of private hospitals as well as public ones.

As in cases involving state licensing boards, federal courts are likely to give inadequate weight to federal antitrust policy if they unthinkingly (or thinkingly) embrace the professional paradigm and its presumption that self-regulation is in the public interest in the case of competitors of certain elite types. In medicine, the professional paradigm not only assumes that physicians can be trusted to regulate themselves but also holds that they should not be appreciably accountable to lay interests, either government regulators or corporate entities providing or financing patient care. ${ }^{44}$ Yet it is precisely this paradigm that federal antitrust authorities must be free to call into question, at least to the extent of forcing state legislators who wish to embrace it both to do so explicitly and to supply an alternative to competition as a protection for consumers. The state action doctrine should be used to encourage, not to frustrate, such applications of a federal policy that, though narrowly focused, is both clear and strong.

\section{Other Business Practices of Public Hospitals}

Public hospitals are sometimes sued for violating the antitrust laws by entering into unlawful agreements, joint ventures, or anticompetitive mergers or by employing monopolistic practices. Some courts have found them immune from such suits by virtue of their enabling acts, which typically empower them to make contracts and otherwise to conduct business like private firms. Analogizing hospital districts to municipalities, these courts have found their anticompetitive conduct sufficiently foreseeable to warrant shielding them from accountability under federal antitrust rules. The law has left the door open, however, to imposing a stricter cleararticulation test whenever a municipality is engaged, not in regulating local business, but in commercial activities as a competitor of private firms. ${ }^{45}$ Applying this so-called market-participant exception to public hospitals would yield satisfying outcomes.

44. Havighurst (1990).

45. City of Columbia v. Omni Outdoor Advertising, Inc., 499 U.S. 365, 374-375 (1991) (stating that state action "immunity does not necessarily obtain where the State acts not in a regulatory capacity but as a commercial participant in a given market"). 
In a thoughtful en banc opinion rejecting state action immunity for a public hospital charged with monopolistic practices affecting a private competitor, the Fifth Circuit court of appeals has observed "a distinction between a statute that in empowering a municipality necessarily contemplates the anticompetitive activity from one that merely allows a municipality to do what other businesses can do." 46 In situations where subdivisions of the state are engaged in such nongovernmental functions, it is reasonable to expect them to possess explicit rather than merely implicit legislative authority for their anticompetitive acts. Whereas municipal officials are directly accountable to voters for their performance of their ordinary governmental functions, boards of public hospitals are not. Although public hospitals are unlike state licensing boards in not being accountable to specific private interests, their incentives and institutional impulses differ very little from those of private firms, suggesting the appropriateness of applying antitrust principles to govern their behavior.

\section{Provider-Cooperation Laws}

In recent years, a number of states have enacted so-called provider-cooperation laws intended to enable health care providers (mostly hospitals) to merge or otherwise collaborate without being subject to federal antitrust law. 47 These laws specifically seek to circumvent federal constraints by satisfying the two requirements of the Midcal doctrine, first by expressing the legislature's desire to override federal competition policy and, second, by providing some form of state oversight (usually by the state attorney general) of any anticompetitive actions that providers might take pursuant to the state's authority. Surprisingly, these laws have not been much used as a safe harbor for hospital mergers, perhaps because hospitals have not found the prospect of being actively supervised by the state attorney general to be attractive. Although it is unsettled whether a hospital merger creating a local monopoly would thereafter need to have its prices approved by the state to avoid having the merger challenged retroactively

46. Surgical Care Center of Hammond v. Hospital Service District No. 1 of Tangipahoa Parish, 171 F.3d 231, 235 (5th Cir. 1999) (en banc). For a troublesome earlier case, see FTC v. Hospital Board of Directors of Lee County, 38 F.3d 1184 (11th Cir. 1994) (held to be enough that "the acquisition of one of the three competing hospitals in Lee County was a foreseeable result of the Florida legislature's granting the Board the authority to add new facilities to its operation"). See generally Ward (2000).

47. See generally Blumstein (1996). 
by the antitrust authorities, anything less would seem to leave consumers without protections comparable to those that competition is presumed to provide.

A more subtle effect of these laws, particularly in the merger context, may be to diminish the ability of the antitrust agencies to stop an objectionable merger by threatening legal action if it is consummated. As long as the hospitals have the alternative of obtaining state approval and thus arguable antitrust immunity under the state action doctrine, the agencies might be inclined to approve borderline mergers rather than have the parties attempt this end run around their authority. It would not be a surprise if the agencies, preferring not to test the limits of their powers in the face of provider-cooperation laws, sometimes refrain from challenging a merger that they fear state officials would approve, thus leaving the public prey to unsupervised market power.

A variation of these laws in a few states seeks to protect physicians against federal antitrust restrictions on collective bargaining with health insurers and health plans. Although these statutes permit collective bargaining at least in circumstances where competition among health plans is deemed insufficient to prevent exploitation of physicians, they generally stop short of authorizing concerted refusals to deal with (i.e., group boycotts of) health plans. Thus, because physicians lack both the right to strike and the protections of federal labor law, they have found it difficult to get payers to sit down with them and actually negotiate their grievances. Consequently, it may be hard to know whether these laws have had much practical effect in the marketplace. Even so, the FTC has actively (and rightly) opposed their enactment. On the other hand, state medical societies continue to press for such laws, perhaps only to demonstrate to their members that they are working to help them out in markets where they perceive themselves to be price takers rather than price setters.

\section{Conclusion}

In a great many cases, the state action doctrine of federal antitrust law has been useful to courts in enabling them to grant summary judgment in private antitrust cases that almost certainly lacked substantive merit but that would have been difficult to dismiss summarily on substantive grounds because of a lack of clarity in the law or in the facts of the case. But reading the state action doctrine overbroadly to reach expeditious outcomes in such cases appears to have made it unduly difficult in other situations for 
antitrust enforcers and other plaintiffs to challenge real trade restraints imposed under color of state law. ${ }^{48}$ Greater judicial awareness of the benefits of competition in markets for professional and other health services and of the ease with which such competition is frequently curtailed by licensing and regulatory boards or hospital medical staffs claiming to act on state authority should result in greater rigor and discrimination in applying the Midcal tests for state action immunity. There is thus good reason for federal courts, which are charged in such cases with balancing federalism concerns against federal antitrust policy, to give more weight to the latter by expecting more explicitness by state legislatures in situations where there is an apparent risk (detectable in conflicts of interests of those actually making state competition policy) that private rather than public interests will be served. The DOJ and FTC might have done an even greater public service if, in their recent report endorsing a prominent role for competition in health care, they had expressed greater urgency about the need to open the anticompetitive actions of certain state-chartered actors to greater accountability under federal antitrust principles.

\section{References}

Arrow, Kenneth, J. 1963. Uncertainty and the Welfare Economics of Medical Care. American Economic Review 53: 941-973.

Blumstein, J. F. 1996. Assessing Hospital Cooperation Laws. Loyola Consumer Law Reporter 8: 248-268.

Department of Justice. Antitrust Division. 2005. Public Comment and Response on Proposed Final Judgment. Federal Register 70: 40058-62.

Federal Trade Commission/Department of Justice (FTC/DOJ). 2004. Improving Health Care: A Dose of Competition. Washington, DC: FTC/DOJ. www.usdoj .gov/atr/public/health_care/204694.htm\#toc.

Freidson, E. 2001. Professionalism: The Third Logic. Chicago: University of Chicago Press.

Havighurst, C. C. 1984. Doctors and Hospitals: An Antitrust Perspective on Traditional Relationships. Duke Law Journal 1984: 1071-1162.

1990. The Professional Paradigm of Medical Care: Obstacle to Decentralization. Jurimetrics Journal 30: 415-429.

48. See note 40 and accompanying text. See also the Earles case, notes 31-34 and accompanying text, for a good example of a case in which the court seized a tempting opportunity to stretch the state action doctrine in order to quickly dismiss a clearly meritless case but in so doing left the law in a troublesome state. 
. 2000. American Health Care and the Law-We Need to Talk! Health Affairs 19: 84-106.

- 2001. Health Care as a (Big) Business: The Antitrust Response. Journal of Health Politics, Policy and Law 26: 939-955.

- 2002. How the Health Care Revolution Fell Short. Law and Contemporary Problems 65(4): 55-101.

- 2003. An Apology for Professionalist Regimes. Journal of Health Politics, Policy and Law 28: 159-164.

Havighurst, C. C., J. F. Blumstein, and T. A. Brennan. 1998. Health Care Law and Policy: Readings, Notes, and Questions. New York: Foundation.

Office of Policy Planning. Federal Trade Commission. 2003. Report of the State Action Task Force. Washington, DC: Federal Trade Commission.

Page, W. H. 1987. Interest Groups, Antitrust, and State Regulation. Duke Law Journal 4: 618-668.

Page, W. H., and J. E. Lopatka. 1994. State Regulation in the Shadow of Antitrust: FTC v. Ticor Title Insurance Co. Supreme Court Economic Review 3: 189-237.

Pierce, R., S. Shapiro, and P. Verkuil. 1992. Administrative Law and Procedure. Sec. 3.4. 2nd ed. New York: Foundation.

Starr, P. 1982. The Social Transformation of American Medicine. New York: Basic Books.

Ward, P. C. 2000. State Action Antitrust Immunity for Public Hospitals: It Depends on What You Mean by “Foreseeable.” Journal of Health Law 33: 1-24. 
- 